4-13-1991

\title{
Our First Televised Genocide
}

Kenneth Lasson

University of Baltimore School of Law, klasson@ubalt.edu

Follow this and additional works at: http://scholarworks.law.ubalt.edu/all_fac

Part of the Civil Rights and Discrimination Commons, International Humanitarian Law Commons, International Law Commons, and the Military, War, and Peace Commons

\section{Recommended Citation}

Our First Televised Genocide, The Baltimore Sun, April 13, 1991

This Editorial is brought to you for free and open access by the Faculty Scholarship at ScholarWorks@University of Baltimore School of Law. It has been accepted for inclusion in All Faculty Scholarship by an authorized administrator of ScholarWorks@University of Baltimore School of Law. For more information, please contact snolan@ubalt.edu. 


\author{
Related Articles \\ NATO's police powers \\ April 1, 1999 \\ Sun News Digest \\ April 5, 2006 \\ Heart of Darkness RE-EXAMINING RWANDA \\ April 21, 1996 \\ Fuzzy Line in the Gulf \\ October 21, 1990 \\ The illogic of intervention \\ April 4, 1991
}

\section{Find More Stories About}

Saddam Hussein

Genocide

\section{Our First Televised Genocide}

April 13, 1991 | By KENNETH LASSON

Whoever saves one life, it is as if he has saved the world. (Talmudic saying)
KENNETH LASSON

$\begin{array}{lll}\text { Recommend } & \sqrt{0} & \\ \text { Tweet } & \bullet \vdots & 0 \\ & \bullet \vdots & \mathrm{G}+1\end{array}$

For the Kurds, the world is not a place worth living in.

Even as we bear witness to history's first televised genocide, the images are at once exquisitely poignant and horrifyingly ineffective. Babies crying for food -- unaware that their mothers can provide none, much less that governments haven't -- should be enough to make us all weep in dismay.

Instead, we are reduced to muttering sympathetic pieties or intoning inedible platitudes -- force-feeding political science to empty-eyed innocents dying on godforsaken mountainsides.

It is absolutely appalling that we have come so casually to observe the carnage, so passively to view the starvation over breakfast papers or dinnertime newscasts, so helplessly to watch these totally bereft human beings trudging barefoot over treacherous terrain toward the middle of nowhere.

What is absolutely needed should be shockingly clear: to provide, immediately and unconditionally, food, clothing, shelter and defense to all the Kurdish refugees.

Feeding desperate people is surely not beyond our logistical capabilities, nor need it be seen as an act of colonialism The academically obvious political considerations -- that we must refrain from "interfering in the internal affairs of a sovereign nation," that we needn't be "the world's policeman," that we should "encourage self-determination" -- can all come later, after the lives had been saved.

There are other questions as well, of course, not as easily answered. Where are all their voices now, those demonstrators who so vociferously opposed war, ostensibly out of an overweening reverence for life? Is the latter-day holocaust being systematically perpetrated in northern Iraq any less horrifying than a direct hit on a camouflaged bomb shelter in Baghdad? If Saddam Hussein were herding civilians into concentration camps and burning them in crematoria, would we be so deferential to U.N. imperatives or future foreign-policy implications? Is there a distinction to be drawn between death by gassing and death by helicopter gunship?

Had there been network pictures from Auschwitz in 1943, would the Allies still have declined to "meddle"?

In truth we need no excuse to go in and save the Kurds. In truth, though, we created the immediate conditions for this tyrannical rampage; we have good reason to intervene, even to change the terms of the cease-fire we rightly dictated; and we have the means, if not to destroy the monster, to stop him once again in his tracks as he seeks to annihilate his opposition to the last woman and child.

Let us not blink an instant to save these lives. Economic sanctions can't be eaten. For America, a nation for its soul, here is another chance. With military supremacy established and troops still in place, we may never have a better opportunity to put our moral might into practice.

*Kenneth Lasson is a law professor at the University of Baltimore.

From the Web

Sponsored Links

Maryland: Drivers Are Stunned By This New Rule

Provide Savings Insurance Quotes

Do You Binge-Watch Documentaries? You'll Love This Website LA Times | Curiosity Stream

Pay Off Your House At A Furious Pace If You Owe Less Than \$625k LowerMyBills

Why This Shirt Company Is Causing so Many Guys to Switch Proper Cloth

Ron Paul Issues Warning On Gold

Stansberry Research 
10 Clothes Middle-Aged Women Should Avoid

Lifescript

See The Online Furniture Store That Has Retailers Worried Wayfair

This Service in Baltimore is Changing the Way People Cook at Home HelloFresh

by Taboola

\section{MORE:}

\begin{tabular}{l|l} 
A tale of customer service, & 7 Ways Michael Jackson Changed The World
\end{tabular}

justice and currency as funny as

a $\$ 2$ bill

Why expansion tank is needed

Family's bad fortunes propelled

Thomas to better life

'Blushing' ear is no cause for alarm

Minor's future arrives early Rookie didn't expect to make

a start at third this season 